\title{
Immunopathologic differences of Sjögren's syndrome versus sicca syndrome in HCV and HIV infection
}

\author{
Claudio Vitali*
}

\begin{abstract}
A clinical picture of dry eye and dry mouth with the histological counterpart of focal lymphocytic sialoadenitis, usually detected in minor salivary glands, is considered the hallmark of Sjögren's syndrome. The association of sicca complaints and focal sialoadenitis can be also found in a number of other diseases, including some systemic viral infections. Among these conditions, chronic hepatitis C virus infection, associated with mixed cryoglobulinaemia and extrahepatic manifestations, and HIV infection, particularly in the phase of diffuse interstitial lymphocytic infiltration, may mimic the clinical and histological aspects of Sjögren's syndrome. However, each disorder is characterised by specific, disease-related immunopathological aspects. Besides sicca complaints, the various disorders may also share a number of systemic extra-glandular features and the possible development of mucosa-associated lymphoid tissue lymphomas. This latter event represents in all of these diseases the final result of an antigen-driven chronic stimulation of B lymphocytes.
\end{abstract}

\section{Introduction}

Sjögren's syndrome (SS) is a chronic systemic autoimmune disease mainly affecting the exocrine glands. For this reason, the definition of autoimmune exocrinopathy has been proposed in the past for this disorder [1]. Behind the involvement of exocrine glands (predominantly the lachrymal and the salivary glands), other nonexocrine epithelial lesions may be observed in a large number of patients. Consequently, the disease has been alternatively termed as autoimmune epithelitis [2].

*Correspondence: c.vitali@yahoo.it

Department of Internal Medicine and Section of Rheumatology, 'Villamarina' Hospital, 57025 Piombino, Italy
Finally, autoantibody-mediated or immune-complexmediated vasculitic lesions - compromising various organs or systems, such as the peripheral or central nervous system, skin, lung or kidney - may complicate the disease course, in a more limited number of patients. This justifies the inclusion of SS among the systemic autoimmune diseases [3]. Furthermore, SS has received the attribute primary (pSS) when it appears alone, or secondary when it is associated with another well-defined systemic autoimmune disease, such as systemic lupus, rheumatoid arthritis or systemic sclerosis [4].

The presence of focal lymphomonocytic infiltrates in the target organs, particularly in the salivary and lachrymal glands, has been considered the hallmark of the disease. The focus consists of an agglomerate of inflammatory cells, mainly lymphocytes, which are located around the acinar and ductal structures of the glands. The presence of at least 50 mononuclear cells is the conventionally accepted definition for the focus [5]. Because of the difficulty in obtaining lachrymal gland tissue, and the fear of causing facial nerve palsy or parotid fistulae in performing parotid gland biopsy, obtaining glandular tissue from minor salivary glands (MSGs) has been proposed as a more easily and less invasive approach for the histologic analysis of the target tissue [5]. The biopsy of sublingual glands has been alternatively suggested, but it seems to be a more complicated surgical way to take a sample of gland salivary tissue [6]. However, the existence of some important differences between the histological features found in major and minor salivary glands has been pointed out in several studies, and the biopsy of the parotid has been recently re-evaluated as an easy and safe method of obtaining salivary tissue [7].

A sufficient number of gland lobuli for histological examination can be obtained without any particular difficulty by performing a MSG biopsy on the lower lip. A permanent, although limited, sensory loss of the mucosa of the lower lip - occurring in a minority of patients - is the only known complication of a labial biopsy [7]. Several authors also proposed different scoring systems of focal infiltrates observed in MSGs, and also the 
minimal score needed to define a diagnosis of SS $[5,8,9]$. Moreover, some authors proposed that the presence of a given focal score in MSGs could be the mandatory criterion to classify a patient as having SS [5]. This point has been debated for a long time by the scientific community. The American-European Consensus Criteria for the classification of SS finally established that, among the six items composing the criteria set, either focal sialoadenitis at MSG biopsy (with a focus score $\geq 1$ for $4 \mathrm{~mm}^{2}$ glandular tissue) or the presence of specific autoantibodies should be mandatory for the diagnosis of pSS [10].

Salivary glands (and also lachrymal glands) are not the exclusive inflammatory targets for SS. Sicca features may be part of the clinical picture of other disorders, in which a focal sialoadenitis, with histological characteristics evocative of SS, can be found [11]. Besides sarcoidosis, where a focal granulomatosous sialoadenitis has been described, and the histological examination of MSGs can be useful in some cases to define diagnosis [12], even hepatitis $\mathrm{C}$ virus (HCV) [13] and HIV [14] infections may exhibit, in different phases of the disease, sicca complaints, with the histological counterpart of a focal sialoadenitis. This induced the American-European Consensus Group for the Classification of SS to list HCV and HIV infections among the exclusion criteria for SS [10].

In clinical practice, however, the presence of these overlapping features in the various disorders may generate some difficulties in the differential diagnostic definition. These difficulties can certainly be solved, alongside the viral investigations, by better defining the pathological differences between the focal sialoadenitis in the various conditions, using more sophisticated immunopathological techniques. In addition, the evidence that some viral infections may have salivary glands as one of the possible localisations, and that focal sialoadenitis may be the result of the local pathological process, again supports the theory - often proposed, but never completely proven - that some viral agent(s) could trigger the immunopathological cascade in pSS [15].

\section{Immunopathological features of sialadenitis in pSS}

Salivary epithelial cells certainly play a crucial role in the pathological process of pSS. In an adequate environment of stressor agents and hormonal stimulation, and in the presence of a specific genetic background, these cells probably become susceptible to viral aggression. Different viral agents such as Epstein-Barr virus, nonhuman immunodeficiency retroviruses and, more recently, coxsackieviruses $[15,16]$ have been postulated to be capable of triggering pSS. The expression of Toll-like receptor 3 on salivary glands and epithelial cell lines derived from patients affected by pSS may suggest that the engagement of epithelial cells by virus may happen via Toll-like receptor 3 [17]. The inadequate clearance of these viral agents and/or the consequent damage of the epithelial cells initiate a cascade of events that may lead to the selfmaintenance of inflammatory mechanisms and induction of autoimmune manifestations. The insult may induce upregulation of type I interferon by epithelial cells and plasmacytoid dendritic cells, as demonstrated by IFNY RNA overexpression in salivary gland tissue [18]. Secondly, viral injury may induce apoptosis or necrosis of glandular epithelial cells, with the consequent release of autoantigens, which become available for professional antigen-presenting cells [18]. The fact that epithelial cells may also work as nonprofessional antigen-presenting cells is still under debate [19]. This hypothesis has been suggested by the evidence that epithelial cells, when activated, may express class I and class II MHC molecules on their surface [20], together with co-stimulatory molecules [21], and are probably able to engage $T$ cells for the presentation of autoantigens once relocated from the nucleus to the cellular surface [22]. Finally, epithelial cells are certainly important in T-cell recruitment since they produce both intracellular and vascular adhesion molecules [23] and different types of chemotactic factors, including chemokines.

Once $\mathrm{T}$ cells are first attracted into the glandular tissue, they assume the role of the main actors in the inflammatory scene [24], by perpetuating the recruitment of other inflammatory cells, mainly B cells, by expressing a restricted repertoire of T-cell receptors that can recognise autoantigens presented by antigen-presenting cells, and by activating macrophages (via the IFN $\gamma$ signal). These latter cells act as the main agents responsible for further salivary tissue injury, mainly by producing TNF $\alpha$ [25].

The great importance of $\mathrm{T}$ cells in the immmunopathological scenario of pSS is strongly confirmed by the common observation that focal lymphocytic infiltrates are mainly constituted of $\mathrm{T}$ cells with a large predominance of $\mathrm{CD}^{+}{ }^{+}$with respect to the $\mathrm{CD} 8^{+} \mathrm{T}$ cells $(\mathrm{CD} 4 /$ CD8 ratio ranging from 3:1 to 5:1) [24]. B cells represent approximately $20 \%$ of the infiltrating cell population at least in some stages of disease [24]. In addition, macrophages, natural killer cells and dendritic cells are observed in more limited numbers [26]. More recent studies have also shown that two other different T-cell subpopulations are represented in the salivary gland infiltrates. Th17 cells are a distinct $\mathrm{CD}^{+}{ }^{+} \mathrm{T}$-helper cell population expressing IL-17 that are strongly implicated in autoimmune diseases. Increased plasma levels of IL-17 have been observed in SS, and Th17 cells seem to be significantly represented in MSG infiltrates [27]. Transforming growth factor beta (TGF $\beta$ ), IL-23 and IL-6 are the main promoters of the Th17 differentiation and proliferation [27]. TGF $\beta$ is also the pivotal differentiation 
factor of Foxp3 ${ }^{+}$T-regulatory cells, which seems to have an immunosuppressive role in the chronic immunopathologic process [28]. T-regulatory cells have also been found in variable proportions in salivary biopsy specimens of patients with pSS [29].

Recent investigations have shown that the inflammatory cell presence, proportion and organisation may greatly vary in the disease course, and in various subsets of patients, according to disease severity and evolution [30]. $\mathrm{CD}^{+} \mathrm{T}$ cells predominate in mild sialoadenitis and seem to be associated with the presence of a clinically significant articular involvement. The B-cell presence progressively grows from intermediate to severe histological lesions. The predominance of B cells in infiltrates and their organisation in the germinal-centre-like structure is strongly associated with hypergammaglobulinaemia, hypocomplementaemia, rheumatoid factor and autoantibody production, and, from a clinical point of view, with salivary gland swelling, vasculitic manifestations and lymphoproliferation [30]. Foxp $3^{+}$T-regulatory cells are mainly represented in the intermediate grade of lymphocytic infiltration and decline in severe histological lesions $[29,30]$. On the contrary, macrophages are more abundant in severe lesions, as well as dendritic cells. These latter cells are largely represented in more advanced lesions $[26,30]$, and particularly in the germinal-centre-like structure, where they appear to form a network that is essential for the organisation of the infiltrates [30,31]. Finally, IL-17 protein expression progressively increases with a higher focus score, indicating an expansion of the Th17 subpopulation in more severe phases of the disease [30].

The passage from a predominance of $\mathrm{CD} 4^{+}$cells to that of B lymphocytes in glandular infiltrates is therefore characteristic of a more advanced severe disease pattern, which is correlated with systemic manifestations and higher risk of developing lymphoproliferative disorders [32].

B lymphocytes in salivary gland infiltrates in SS are mainly represented by polyclonal $\mathrm{CD} 27^{+}$memory $\mathrm{B}$ cells [33]. Homing of this kind of $B$ cell seems to predominate with respect to local proliferation of a few founder B cells [33]. A large number of chemokines may all contribute to B-lymphocyte homing and chronic maintenance. A particular profile of chemokines, however, is predominantly active in SS. This profile is represented by the CXCL13 and CXCL12 chemokines, which specifically attract $\mathrm{CD} 27^{+}$memory $\mathrm{B}$ cells expressing the corresponding receptors (CXCR4 and CXCR5) [33]. Recent data have shown a large expression of these receptors in the glandular infiltrates of patients with SS. The interaction of B cells attracting chemokines with their specific receptors has been suggested to be essential for B-cell recruitment and organisation in a tertiary germinal-centre-like structure [34].
Behind memory B cells there is a convincing demonstration of the contemporary presence of marginal zone (MZ)-like B cells within the lymphoid infiltrates in SS [35]. These MZ-like B cells may work as reactive B cells against locally expressed autoantigens. Because of the permanent availability of autoantigens, the continuous stimulation of these autoreactive cells leads to the evolution from polyclonal to oligoclonal and then monoclonal selection, and finally to the development of mucosa-associated lymphoid tissue (MALT) B-cell lymphoma [35].

B-cell recruitment, survival, proliferation and organisation are strongly influenced in SS by the large production of B-cell activating factor (BAFF) and a proliferationinducing ligand (APRIL) $[33,35]$. In particular, enhanced levels of BAFF have been shown in most of the systemic autoimmune diseases, usually associated with B-cell hyperactivity. The highest plasma BAFF levels, however, have been found in patients with SS, and a strong local overexpression of this substance has been demonstrated in salivary gland infiltrates [36], particularly in patients with a high focus score. BAFF is produced locally by different cell types, including dendritic cells, $\mathrm{T}$ lymphocytes and macrophages, and certainly plays an important role in local B-cell proliferation, including that of MZ-like B-cell, germinal-centre-like formation, autoantibody production and probably B-cell lymphomagenesis [37].

\section{Immunopathological features of sialadenitis in chronic HCV infection}

Besides hepatocytes and lymphocytes, HCV seems to have a special tropism for lachrymal and salivary epithelial cells. HCV RNA has been found both in saliva and salivary gland tissue [38], and in situ hybridisation studies have clearly demonstrated that $\mathrm{HCV}$ is exclusively localised in the salivary epithelial cell cytoplasma [39]. A chronic focal sialoadenitis, resembling that of SS, can be observed in approximately $50 \%$ of $\mathrm{HCV}$-infected patients, while signs of mild inflammatory infiltration are present in a greater proportion of patients [40]. Sicca symptoms, however, seem to be less frequent and milder in HCVinfected patients. These findings have stimulated a long debate on the possibility that HCV could be considered at least one of the candidate viruses to work as trigger agents for pSS. This hypothesis has been supported by several papers in which $\mathrm{HCV}$ infection appeared to be more prevalent in patients with pSS than in healthy controls (reviewed in [41]). Other data, however, have shown that the prevalence of $\mathrm{HCV}$ infection in patients with defined pSS was similar to that observed in the normal population, and that the overestimation previously reported could by ascribed to different classification criteria used in different studies, and to hypergammaglobulinaemia frequently present in the sera of patients 
with SS [42]. Moreover, the co-existence of $\mathrm{HCV}$ infection and defined pSS (and lymphoma) in the same patients has been sporadically reported, and the demonstration that this association can be ascribed to chance alone is still under discussion [43]. According to the American-European Consensus Criteria, however, evidence of $\mathrm{HCV}$ infection is an exclusion criterion for the classification of a patient as having SS [10].

The amount of information available on the characteristics of the focal infiltrates in salivary glands of HCVinfected patients is not as extensive as that accumulated in SS. This is undoubtedly due to the greater attention devoted to the predominance of liver involvement in $\mathrm{HCV}$ infection, and to the fact that features different from sicca complaints are more clinically significant in HCV infection with extra-hepatic manifestations. Histologic examination of salivary glands in $\mathrm{HCV}$ infected patients shows different aspects with respect to those found in SS patients. Lymphocytic infiltrates often may be located in the pericapillary area rather than around the glandular ducts. In addition, a lack of damage (or mild damage) of the glandular tissue has also been reported $[41,44]$. The lymphocytic subpopulations present in glandular infiltrates appear to be different, sometimes being represented by a predominance of $\mathrm{CD}^{+}$ $\mathrm{T}$ lymphocytes, at least in some areas. More commonly, $\mathrm{CD}^{+} \mathrm{T}$ cells constitute the most represented population in the infiltrates. However, even in this latter case, the CD4/CD8 ratio is usually lower than that observed in SS patients with pSS [44]. There is no demonstration of any translocation and expression of autoantigen peptides in salivary gland epithelial cells, and therefore the corresponding autoantibodies are not detectable in the sera of $\mathrm{HCV}$-infected patients [45]. On the contrary, serum cryoglobulins and hypocomplementaemia are usually found in a large proportion of $\mathrm{HCV}$-infected patients, and are considered markers or predictors for the development of extra-hepatic manifestations of the disease, such as cutaneous vasculitis (cryoglobulinaemic purpura), peripheral neuropathy, glomerulonephritis and sicca syndrome [45].

The pathogenetic mechanism underlying focal sialoadenitis in $\mathrm{HCV}$-infected patients has not so far been clarified. Transgenic mice carrying the HCV envelope genes for E1 and E2 proteins developed an exocrinopathy involving salivary and lachrymal glands [46]. This study clearly indicates a direct role for these viral proteins in the pathogenesis of HCV-related sialoadenitis. Molecular mimicry between $\mathrm{HCV}-\mathrm{E} 2$ protein and an antigenic protein present in exocrine epithelial cells has been suggested as a potential autoimmune mechanism inducing lymphocyte homing and activation [47]. On the other hand, one could simply speculate that the HCV infection of the salivary epithelial cells may be the initial event that is sufficient to induce the activation of innate immunity with the consequent production of proinflammatory cytokines, such as INF $\gamma$ and IL-2, in a way similar to that demonstrated to occur in HCV-infected hepatocytes [48].

\section{Lymphomagenesis in Sjögren's syndrome and HCV chronic infection}

Besides sharing similar clinical and serological features, such as cutaneous vasculitis, peripheral neuropathy and hypocomplementaemia, either patients with chronic $\mathrm{HCV}$ infection associated with mixed cryoglobulinaemia or patients with pSS may develop B-cell lymphomas with a higher prevalence than in the normal population [43]. The most common type of B-cell lymphoma in both disorders is a MZ low-grade lymphoma, where the proliferating cells are rheumatoid factor-positive autoreactive B cells [43]. A significant proportion of $\mathrm{HCV}$-infected patients may also develop diffuse large B-cell lymphoma, probably by completely different pathogenetic mechanisms [49]. In both diseases the low-grade B-cell lymphoma development represents a pathological model of an antigen-driven expansion from polyclonal/oligoclonal to monoclonal proliferation of $\mathrm{B}$ cells [50]. The process is probably driven by autoantigen(s) in SS [43] and by viral antigen(s) in HCV infection [50]. The fact that the process of low-grade B-cell lymphoma development is similar in both conditions is also supported by molecular studies demonstrating a similar restricted usage of genes encoding for heavy and light variable regions and similar somatic mutations of the complementarydetermining region of the surface antigen receptor in monoclonal B cells from patients with SS and HCVrelated mixed cryoglobulinaemia [51].

The site of development of these B-cell lymphomas is typically extra-nodal, since the salivary gland is the preferential site for lymphomas that appear in the course of SS, and the liver and salivary gland are the preferential sites for lymphomas developing in $\mathrm{HCV}$-infected patients with associated sicca complaints [52]. In both conditions, a possible evolution to diffuse large-cell lymphoma has been reported [52].

Clonality studies revealing monoclonal B-cell expansion in target tissues of both conditions are not strictly indicative of lymphoma [53]. These clones may disappear after antiviral therapy in $\mathrm{HCV}$-infected patients [54], or may persist in the same site for a long time without evolving to frank lymphoma. Clonality studies are therefore certainly useful at least to predict possible development of a frank lymphoma.

\section{Sialoadenitis in HIV-infected patients}

HIV-infected individuals are at an increased risk of developing associated rheumatic diseases [55]. Before the 
Table 1. Main clinical, serological, histological, genetic characteristics of focal sialoadenitis

\begin{tabular}{|c|c|c|c|}
\hline Variable & Primary Sjögren's syndrome & Hepatitis $\mathrm{C}$ virus & HIV-related DILS \\
\hline Sicca symptoms & Present & Present & Present \\
\hline Parotid swelling & Moderate to severe & Mild to moderate & Moderate to severe \\
\hline Extra-glandular manifestations & $\begin{array}{l}\text { Mainly pulmonary, gastrointestinal, } \\
\text { renal, and neurologic involvement }\end{array}$ & $\begin{array}{l}\text { Mainly gastrointestinal and musculo- } \\
\text { skeletal involvement }\end{array}$ & $\begin{array}{l}\text { Mainly musculoskeletal, pulmonary, } \\
\text { gastrointestinal, and neurologic } \\
\text { involvement }\end{array}$ \\
\hline Infiltrating lymphocytic phenotype & $\mathrm{CD}^{+} \mathrm{T}$ cells & $\mathrm{CD}^{+} \mathrm{T}$ cells & $\mathrm{CD}^{+} \mathrm{T}$ cells \\
\hline Autoantibodies & $\begin{array}{l}\text { High-frequency RF, ANA, anti-Ro/SSA } \\
\text { and anti-La/SSB }\end{array}$ & $\begin{array}{l}\text { High frequency of RF } \\
\text { Very low frequency of ANA, } \\
\text { anti-Ro/SSA and anti-La/SSB }\end{array}$ & Low-frequency RF, ANA \\
\hline HLA association & $\mathrm{B} 8, \mathrm{DR} 2$ and DR3 & DR-11(DR5) & B45, B49, B50, DR11(DR5), and DRw6 \\
\hline
\end{tabular}

Main characteristics of focal sialoadenitis in primary Sjögren's syndrome, hepatitis C virus-infected patients and HIV-infected patients developing diffuse infiltrative lymphocytosis syndrome (DILS). ANA: antinuclear antibodies; RF, rheumatoid factor. Modified from Basu and colleagues [59].

widespread use of highly active antiretroviral therapy (HAART), retrospective studies calculated the rates of rheumatic manifestations from 11 to $72 \%$ [56]. After the HAART implementation, rheumatic complications declined significantly, with some change in the pattern of the incidental diseases [57].

A SS-like clinical picture may be present in HIVinfected patients who develop diffuse infiltrative lymphocytosis syndrome (DILS). DILS may be present in 3 to $50 \%$ of HIV-infected populations [58]. This great variability between the studies can be ascribed to ethnic differences, to the different criteria used to define the diagnosis (clinical vs. histological) and, finally, to the availability of effective antiviral therapy in the various populations described in the studies. Recent data strongly indicate that, similar to what has been reported for other rheumatic manifestations in HIV infection, the prevalence of DILS has also been remarkably reduced with the introduction of HAART therapy [59]. DILS may mimic pSS because DILS also presents with bilateral painless parotid gland enlargement, lachrymal gland enlargement and sicca symptoms [58]. DILS is characterised by circulating $\mathrm{CD} 8^{+} \mathrm{T}$ cells. The proliferation of $\mathrm{CD}^{+} \mathrm{T}$ cells is probably an antigen-driven process and leads to infiltration of multiple organs, and probably reflects an excessive host response to HIV [60]. The condition usually manifests several years after HIV seroconversion and, besides the lymphocitic infiltration of salivary and lachrymal glands, is characterised by lymphocytic interstitial pneumonitis (31\%), myositis (26\%) and hepatitis (23\%) [61]. DILS differs from pSS by the fact that the occurrence of extra-glandular involvement is more frequent, whilst the presence of autoantibodies and rheumatoid factor is observed in a lower number of patients In addition, the two conditions differ in the nature of infiltrating lymphocytes $\left(\mathrm{CD} 4^{+} \mathrm{T}\right.$ cells in pSS, $\mathrm{CD}^{+}$ $\mathrm{T}$ cells in DILS) and in the association with different HLA haplotypes [58-60].
Interestingly, some cases of MZ indolent MALT lymphomas have rarely been reported in HIV-infected patients [62-64], among the large variety of incidental malignancies described in the course of the disease [65]. MALT lymphoma remission was obtained in these cases after HAART, in a way similar to that observed in HCVrelated and Helicobacter pylori-related MALT lymphoma after specific antiviral and antibiotic therapies [50]. This observation again suggests that infection-related lymphomas derived from MZ B cells may share common antigen-driven mechanisms [50].

\section{Conclusion}

Sicca symptoms and focal sialoadenitis are not exclusive features of pSS, but other diseases may present with involvement of salivary and lachrymal glands and a histological picture of focal infiltration in the target tissues. Beyond viral serology, which may allow one to easily confirm the presence of HCV or HIV infection as the primary causative agent of the syndrome, other clinical, genetic, immunological and histologic findings can help to distinguish pSS from the other SS-like syndromes (Table 1).

The observation that MZ indolent MALT lymphomas may develop in all of these conditions has greatly contributed to a more precise understanding of the intriguing mechanisms of antigen-driven lymphoproliferation.

\footnotetext{
Autoimmune Basis of Rheumatic Diseases

This article is part of a series on Sjögren's syndrome, edited by Thomas Dörner, which can be found online at http://arthritis-research.com/series/Sjögrens

This series forms part of a special collection of reviews covering major autoimmune rheumatic diseases, available at:

http://arthritis-research.com/series/abrd
} 


\section{Abbreviations}

APRIL, a proliferation-inducing ligand; BAFF, B-cell activating factor; DILS, diffuse infiltrative lymphocytosis syndrome; HAART, highly active antiretroviral therapy; HCV, hepatitis C virus; IFN, interferon; IL, interleukin; MALT, mucosaassociated lymphoid tissue; MSG, minor salivary gland; MZ, marginal zone; pSS, primary Sjögren's syndrome; SS, Sjögren's syndrome; Th17, T-helper type 17; TNF, tumour necrosis factor; TGF $\beta$, transforming growth factor beta.

\section{Competing interests}

The author declares that he has no competing interests.

Published: 19 August 2011

\section{References}

1. Fox Rl: Sjögren's syndrome. Lancet 2005, 366:321-331.

2. Mitsias DI, Kapsogeorgou EK, Moutsopoulos HM: The role of epithelial cells in the initiation and perpetuation of autoimmune lesions: lessons from Sjögren's syndrome (autoimmune epithelitis). Lupus 2006, 15:255-261.

3. Hansen A, Lipsky PE, Dörner T: Immunopathogenesis of primary Sjögren's syndrome: implications for disease management and therapy. Curr Opin Rheum 2005, 17:558-565.

4. Theander E, Jacobsoon LTH: Relationship of Sjögren's syndrome to other connective tissue and autoimmune disorders. Rhem Dis Clin North Am 2008, 34:935-947.

5. Daniels TE: Labial salivary gland biopsy in Sjögren's syndrome. Assessment as a diagnostic criterion in 362 suspected cases. Arthritis Rheum 1984, 27:147-156.

6. Pennec YL, Leroy JP, Jouquan J, Lelong A, Katsikis P, Youinou P: Comparison of labial and sublingual salivary gland biopsies in the diagnosis of Sjögren's syndrome. Ann Rheum Dis 1990, 49:37-39.

7. Pijpe J, KalkWWI, van der Wal JE, Vissink A, Kluin PhM, Roodenburg JLN, Bootsma H, Kallenberg CGM, Spijkervet FKL: Parotid gland biopsy compared with labial biopsy in the diagnosis of patients with primary Sjögren's syndrome. Rheumatology 2007, 46:335-341.

8. Chisholm DM, Mason DK: Labial salivary gland biopsy in Sjögren's syndrome. J Clin Pathol 1968, 21:656-660.

9. Tarpley TM, Anderson LG, White CL: Minor salivary gland involvement in Sjögren's syndrome. Oral Surg Oral Med Oral Pathol 1974, 37:64-74.

10. Vitali C, Bombardieri S, Jonsson R, Alexander EL, Carsons SE, Daniels TE, Fox PC, Fox RI, Kassan SS, Pillemer SR, Talal N, Weisman MH: Classification criteria for Sjögren's syndrome: a revised version of the European criteria proposed by the American-European Consensus Group. Ann Rheum Dis 2002, 61:554-558

11. Lindahl $G$, Hedfors $E$ : Focal lymphocytic infiltrates of salivary glands are not confined to Sjögren's syndrome. Scand J Rheumatol 1986, 61(Suppl):52-55.

12. Drosos AA, Voulgari PV, Psychos DN, Tsifetaki N, Bai M: Sicca syndrome in patients with sarcoidosis. Rheumatol Int 1999, 18:177-180

13. Jorgensen C, Legouffe MC, Perney P Coste J, Tissot B, Segarra C, Bologna C, Bourrat $L$, Combe B, Blanc F, Sany J: Sicca syndrome associated with hepatitis C virus infection. Arthritis Rheum 1996, 39:1166-1171.

14. Itescu S, Brancato $L$, Winchester R: A sicca syndrome in HIV infection: association with HLA-DR5 and CD8 lymphocytosis. Lancet 1989, 2:466-468.

15. Venables PJ, Rigby SP: Viruses in the etiopathogenesis of Sjögren's syndrome. J Rheumatol 1997, 50(Suppl):3-5.

16. Triantafyllopoulou A, Tapinos N, Moutsopoulos HM: Evidence for Coxsackievirus infection in primary Sjögren's syndrome. Arthritis Rheum 2004, 50:2897-2902

17. Spachidou MP, Bourazopoulou E, Maratheftis Cl, Kapsogeorgou EK, Moutsopoulos HM, Tzioufas AG, Manoussakis MN: Expression of functional Toll like receptors by salivary gland epithelial cells: increased mRNA expression in cells derived from patients with primary Sjögren's syndrome. Clin Exp Immunol 2007, 147:497-503.

18. Gottenberg JE, Cagnard N, Lucchesi C, Letourneur F, Mistou S, Lazure T, Jacques S, Ba N, Ittah M, Lepajolec C, Labetoulle M, Ardizzone M, Sibilia J, Fournier C, Chiocchia G, Mariette X: Activation of IFN pathways and plasmacytoid dendritic cell recruitment in target organs of primary Sjogren's syndrome. Proc Natl Acad Sci U S A 2006, 103:2770-2775.

19. Patel YI, McHugh NJ: Apoptosis-new clues to the pathogenesis of Sjögren's syndrome? Rheumatology (Oxford) 2000, 39:119-121.

20. Baccala R, Kono DH, Theofilopoulos AN: Interferons as pathogenic effectors in autoimmunity. Immunol Rev 2005, 204:9-26.
21. Matsumura R, Umemiya K, Goto T, Nakazawa T, Kagami M, Tomioka H, Tanabe E, Sugiyama T, Sueishi M: Glandular and extraglandular expression of costimulatory molecules in patients with Sjögren's syndrome. Ann Rheum Dis 2001, 60:473-482

22. McArthur C, Wang Y, Veno P, Zhang J, Fiorella R: Intracellular trafficking and surface expression of SS-A (Ro), SS-B (La), poly(ADP-ribose) polymerase and alpha-fodrin autoantigens during apoptosis in human salivary gland cells induced by tumour necrosis factor-alpha. Arch Oral Biol 2002 47:443-448.

23. Kapsogeorgou EK, Dimitriou ID, Abu-Helu RF, Moutsopoulos HM, Manoussakis MN: Activation of epithelial and myoepithelial cells in the salivary glands of patients with Sjögren's syndrome: high expression of intercellular adhesion molecule-1 (ICAM.1) in biopsy specimens and cultured cells. Clin Exp Immunol 2001, 124:126-133.

24. Katsifis GE, Moutsopoulos NM, Wahl SM: T lymphocytes in Sjögren's syndrome: contributors to and regulators of pathophysiology. Clin Rev Allergy Immunol 2007, 32:252-264.

25. Matsumura R, Umemiya K, Kagami M, Tomioka H, Tanabe E, Sugiyama T, Sueishi M, Kayagaki N, Yagita H, Okumura K: Expression of TNF-related apoptosis inducing ligand (TRAIL) on infiltrating cells and of TRAIL receptors on salivary glands in patients with Sjögren's syndrome. Clin Exp Rheumatol 2002, 20:791-798.

26. Manoussakis MN, Boiu S, Korkolopoulou P, Kapsogeorgou EK, Kavantzas N, Ziakas P, Patsouris E, Moutsopoulos HM: Rates of infiltration by macrophages and dendritic cells and expression of interleukin-18 and interleukin-12 in the chronic inflammatory lesions of Sjogren's syndrome: correlation with certain features of immune hyperactivity and factors associated with high risk of lymphoma development. Arthritis Rheum 2007 56:3977-3988.

27. Katsifis GE, Rekka S, Moutsopoulos NM, Pillemer S, Wahl SM: Systemic and local interleukin-17 and linked cytokines associated with Sjögren's syndrome immunopathogenesis. Am J Pathol 2009, 175:1167-1177.

28. Lan RY, Ansari AA, Lian ZX, Gershwin ME: Regulatory T cells: development, function and role in autoimmunity. Autoimmun Rev 2005, 4:351-363.

29. Christodoulou MI, Kapsogeorgou EK, Moutsopoulos NM, Moutsopoulos HM: Foxp $3^{+}$T-regulatory cells in Sjögren's syndrome: correlation with the grade ofthe autoimmune lesion and certain adverse prognostic factors. Am J Pathol 2008, 173:1389-1396.

30. Christodoulou MI, Kapsogeorgou EK, Moutsopoulos HM: Characteristics of the minor salivary gland infiltrates in Sjögren's syndrome. J Autoimmun 2010, 34:400-407

31. Bombardieri M, Barone F, Humby F, Kelly S, McGurk M, Morgan P, Challacombe S, De Vita S, Valesini G, Spencer J, Pitzalis C: Activation-induced cytidine deaminase expression in follicular dendritic cell networks and interfollicular large B cells supports functionality of ectopic lymphoid neogenesis in autoimmune sialoadenitis and MALT lymphoma in Sjögren's syndrome. J Immunol 2007, 179:4929-4938.

32. Gottenberg JE, Busson M, Cohen-Solal J, Lavie F, Abbed K, Kimberly RP, Sibilia J, Mariette X: Correlation of serum B lymphocyte stimulator and beta-2 microglobulin with autoantibody secretion and systemic involvement in primary Sjögren's syndrome. Ann Rheum Dis 2005, 64:1050-1055.

33. Hansen A, Lipsky PE, Dörner T: B cells in Sjögren's syndrome: indications for disturbed selection and differentiation in ectopic lymphoid tissue. Arthritis Res Ther 2007, 9:218-230.

34. Barone F, Bombardieri M, Manzo A, Blades MC, Morgan PR, Challacombe SJ, Valesini G, Pitzalis C: Association of CXCL13 and CCL21 expression with the progressive organization of lymphoid-like structures in Sjögren's syndrome. Arthritis Rheum 2005, 52:1773-1784.

35. Youinou P, Devauchelle-Pensec V, Pers J-O: Significance of B cells and B cell clonality in Sjögren's syndrome. Arthritis Rheum 2010, 62:2605-2610.

36. Lavie F, Miceli-Richard C, Quillard J, Roux S, Leclerc P, MarietteX: Expression of BAFF (BLys) in T cell infiltrating labial salivary glands from patients with Sjögren's syndrome. J Patho/ 2004, 202:496-502.

37. Ittah M, Miceli-Richard C, Gottenberg JE, Lavie F, Lazure T, Ba N, Sellam J, Lepajolec C, Mariette X: B-cell activating factor of the tumor necrosis factor family (BAFF) is expressed under stimulation by interferon in salivary gland epithelial cells in primary Sjögren's syndrome. Arthritis Res Ther 2006, 8:R51.

38. Toussirot E, Le Huédé G, Mougin C, Balblanc JC, Bettinger D, Wendling D: Presence of hepatitis $C$ virus RNA in the salivary glands of patients with Sjögren's syndrome and hepatitis C virus infection. J Rheumatol 2002, 
29:2382-2385

39. Arrieta JJ, Rodriguez-Ingo E, Ortiz-Movilla N, Bartolomé J, Pardo M, Manzarbeitia F, Oliva H, Macias DM, Carreno V: In situ detection of hepatitis C virus RNA in salivary glands. Am J Pathol 2001, 158:259-264.

40. Loustaud-Ratti V, Riche A, Liozon E, Labrousse F, Soria P, Rogez S, Babany G, Delaire L, Denis F, Vidal E: Prevalence and characteristics of Sjögren's syndrome or Sicca syndrome in chronic hepatitis $C$ virus infection: a prospective study. J Rheumatol 2001, 28:2245-2251.

41. M Carrozzo: Oral diseases associated with hepatitis $C$ virus infection. Part 1: sialadenitis and salivary glands lymphoma. Oral Dis 2008, 14:123-130.

42. Vitali C, Sciuto M, Neri R, Greco F, Mavridis AK, Tzioufas A, Tsianos EV: Antihepatitis C virus antibodies in primary Sjögren's syndrome: false positive results are related to hyper-gamma-globulinaemia. Clin Exp Rheumatol 1992, 10:103-104.

43. Ramos-Casals M, De Vita S, Tzioufas AG: Hepatitis C virus, Sjögren's syndrome and B-cell lymphoma: linking infection, autoimmunity and cancer. Autoimmun Rev 2005, 4:8-15.

44. Freni MA, Artuso D, Gerken G, Spanti C, Marafioti T, Alessi N, Spadaro A, Ajello $A$, Ferraù $O$ : Focal lymphocytic aggregates in chronic hepatitis $C$ : occurrence, immunohistochemical characterization, and relation to markers of autoimmunity. Hepatology 1995, 22:389-394.

45. Ramos-Casals M, Font J: Extrahepatic manifestations in patients with chronic hepatitis C virus infection. Curr Opin Rheumatol 2005, 17:447-455.

46. Koike K, Moriya K, Ishibashi K, Yotsuyanagi H, Shintani Y, Fujie H, Kurokawa K, Matsuura Y, Miyamura T: Sialadenitis histologically resembling Sjögren's syndrome in mice transgenic for hepatitis $C$ virus envelope genes. ProC Natl Acad Sci USA 1997, 94:233-236.

47. Ohoka S, Tanaka Y, Amako Y, Kohara M, Ishidate K, Watanabe M, Takahashi Y, Sato C: Sialadenitis in patients with chronic hepatitis $C$ is not directly related to hepatitis C virus. Hepatol Res 2003, 27:23-29.

48. Rehermann B: Hepatitis $C$ virus versus innate and adaptive immune responses: a tale of coevolution and coexistence. J Clin Invest 2009, 119:1745-1754.

49. Machida K, Cheng KT, Sung VM, Shimodaira S, Lindsay KL, Levine AM, Lai MY, Lai MM: Hepatitis C virus induces a mutator phenotype: enhanced mutations of immunoglobulin and protooncogenes. Proc Natl Acad SCi USA 2004, 101:4262-4267.

50. Suarez F, Lortholary $\mathrm{O}$, Hermine $\mathrm{O}$, Lecuit M: Infection-associated lymphomas derived from marginal zone B cells: a model of antigen-driven lymphoproliferation. Blood 2006, 107:3034-3044.

51. De Re V, De Vita S, Gasparotto D, Marzotto A, Carbone A, Ferraccioli G, Boiocchi M: Salivary gland B cell lymphoproliferative disorders in Sjögren's syndrome present a restricted use of antigen receptor gene segments similar to those used by hepatitis C virus-associated non-Hodgkins's lymphomas. Eur J Immuno/ 2002, 32:903-910.

52. Ramos-Casals M, la Civita L, de Vita S, Solans R, Luppi M, Medina F, Caramaschi P, Fadda P, de Marchi G, Lopez-Guillermo A, Font J; SS-HCV Study Group: Characterization of B cell lymphoma in patients with Sjögren's syndrome and hepatitis C virus infection. Arthritis Rheum 2007, 57:161-170.

53. De Vita S, Boiocchi M, Sorrentino D, Carbone A, Avellini C, Dolcetti R, Marzotto
A, Gloghini A, Bartoli E, Beltrami CA, Ferraccioli G: Characterization of prelymphomatous stages of B cell lymphoproliferation in Sjögren's syndrome. Arthritis Rheum 1997, 40:318-331.

54. Vallisa D, Bernuzzi P, Arcaini L, Sacchi S, Callea V, Marasca R, Lazzaro A, Trabacchi E, Anselmi E, Arcari AL, Moroni C, Bertè R, Lazzarino M, Cavanna L: Role of anti-hepatitis C virus (HCV) treatment in HCV-related, low-grade, B-cell, non-Hodgkin's lymphoma: a multicenter Italian experience. J Clin Oncol 2005, 23:468-473.

55. Medina-Rodriguez F, Guzman C, Jara LJ, Hermida C, Alboukrek D, Cervera H, Miranda JM, Fraga A: Rheumatic manifestations in human immunodeficiency virus positive and negative individuals: a study of 2 populations with similar risk factors. J Rheumatol 1993, 20:1880-1884

56. Buskila D, Gladman DD, Langevitz P, Bookman AA, Fanning M, Salit IE: Rheumatologic manifestations of infection with the human immunodeficiency virus(HIV). Clin Exp Rheumatol 1990, 8:567-573.

57. Calabrese LH, Kirchner E, Shrestha R: Rheumatic complications of human immunodeficiency virus infection in the era of highly active antiretroviral therapy: emergence of a new syndrome of immune reconstitution and changing patterns of disease. Semin Arthritis Rheum 2005, 35:166-174.

58. Kordossis T, Paikos S, Aroni K, Kitsanta P. Dimitrakopoulos A, Kavouklis E, Alevizou V, Kyriaki P, Skopouli FN, Moutsopoulos HM: Prevalence of Sjögren's-like syndrome in a cohort of HIV-1-positive patients: descriptive pathology and immunopathology. Br J Rheumatol 1998, 37:691-695.

59. Basu D, Williams FM, Ahn CW, Reveille JD: Changing spectrum of the diffuse infiltrative lymphocytosis syndrome. Arthritis Rheum 2006, 55:466-472.

60. Panayiotakopoulos GD, Aroni K, Kyriaki D, Paikos S, Vouyioukas N, Vlachos A, Kontos AN, Kordossis T: Paucity of Sjögren's-like syndrome in a cohort of HIV-1-positive patients in the HAART era: part II. Rheumatology (Oxford) 2003, 42:1164-1167.

61. Kazi S, Cohen PR, Williams F, Schempp R, Reveille JD: The diffuse infiltrative lymphocytosis syndrome. Clinical and immunogenetic features in 35 patients. AIDS 1996, 10:385-391.

62. Ishimaru F: Regression of HIV-associated mucosa-associated lymphoid tissue lymphoma during highly active anti-retroviral therapy [letter]. Clin Infect Dis 2008, 46:1124.

63. Levine AM, Sadeghi S, Espina B, Tulpule A, Nathwani B: Characteristics of indolent non-Hodgkin lymphoma in patients with type 1 human immunodeficiency virus infection. Cancer 2002, 94:1500-1506.

64. Girard T, Luquet-Besson I, Baran-Marszak F, Raphael M, Boue F: HIV+ MALT lymphoma remission induced by highly active antiretroviral therapy alone. Eur J Haemato/ 2005, 74:70-72

65. Launay O, Guillevin L: Epidemiology of HIV-associated malignancies. Bull Cancer 2003, 90:387-392.

\section{doi:10.1186/ar336}

Cite this article as: Vitali C: Immunopathologic differences of Sjögren's syndrome versus sicca syndrome in HCV and HIV infection. Arthritis Research \& Therapy 2011, 13:233. 